\title{
Soil Acidity and Its Management Options in Western Ethiopia: Review
}

\author{
Bikila Takala \\ Ethiopian Institute of Agricultural Research; Jimma Agricultural Research Center, \\ P.O Box 192, Jimma, Ethiopia
}

\begin{abstract}
Soil acidity has become a serious threat to crop production in most highlands of Ethiopia in general and in the western part of the country in particular. An earlier study estimated that about $41 \%$ of arable lands of Ethiopia are affected by soil acidity/ $\mathrm{Al}^{3+}$ toxicity. But recently the status of most soil in western Ethiopia were became acidic though the degree varied from location to location; severely limiting crop production. In western Ethiopia acidification occurs simultaneously with other conditions including eroded topsoil and depleted organic matter, depleted nutrients, and alternating drought stress and high rainfall which is high enough to leach appreciable amounts of exchangeable basic cations. In moisture-stressed areas, acidification can also be caused by continuous application of acid-forming chemical fertilizers. As low $\mathrm{pH}$ affects the availability of nutrients particularly that of phosphorus and other macronutrients, correction of the low $\mathrm{pH}$ through liming, and/or application of organic materials is critical for sustainable management of these soils. Agricultural liming is proved a good way of correcting soil $\mathrm{pH}$ along with supplying calcium to the soil. Another potential organic amendment sources in coffee producing areas of western Ethiopia were coffee pulp and husk, by products from wet and dry coffee processing respectively. These coffee by-products are utilized in other coffee producing countries as soil amendments especially in highly weathered soils. While in Western Ethiopia enormous quantities are either dumped into streams or burnt in big piles, with contributions to environmental hazards. Therefore, farmers should be encouraged to increase productivity of the acidic soils by using lime and organic amendments which is easily available such as composted coffee wastes (coffee husk and pulp).
\end{abstract}

Keywords: Soil acidity, lime, organic amendment, coffee husk and pulp

DOI: $10.7176 / \mathrm{JEES} / 9-10-04$

Publication date:October $31^{\text {st }} 2019$

\section{Introduction}

Acid soils make up approximately $30 \%$ of the world's total land area and more than $50 \%$ of the world's potentially arable lands, particularly in the tropics and subtropics (Sumner and Noble, 2003; Kochian et al., 2004 and Kochian et al., 2015). Thus, acid soils limit crop yields in many developing countries where food production is critical. Acid soils are phyto-toxic due to nutritional disorders, deficiencies, unavailability of essential nutrients such as calcium, magnesium, molybdenum, and phosphorus, and toxicity of aluminum, manganese, and hydrogen activity (Ritchie, 1998; Hede et al., 2001; Taye, 2007). The dominance of aluminum on the ion exchange complex in acid soils directly affects plant growth particularly agronomic crops (Kochian et al., 2004). Aluminum toxicity is a particular management problem and occurs mainly when $\mathrm{pH}$ in water is less than 5.0 (Menzies, 2003; Robarge, 2008). The increasing trend of soil acidity and exchangeable $\mathrm{Al}^{3+}$ in arable and abandoned lands are attributed to intensive cultivation and continuous use of acid forming inorganic fertilizers (Abdenna et al., 2007).

Other changes in soils that may occur during soil acidification include loss of nutrients due to leaching, loss or reduction in the availability of certain plant nutrients (such as $\mathrm{P}, \mathrm{Ca}, \mathrm{Mg}$, and $\mathrm{Mo}$ ), an increase in the solubility of toxic metals such as $\mathrm{Al}$ and $\mathrm{Mn}$, which may influence root growth and nutrient and water uptake, and a change in microbial populations and activities (Fageria and Baligar, 2003; Menzies, 2003; Marschner, 2012; Abdenna et al., 2013). Such changes will often be accompanied by changes in overall soil $\mathrm{pH}$, but the degree of change will be dependent on a combination of properties within a given soil (Fageria and Baligar, 2008).

In Ethiopia acidification occurs simultaneously with other conditions including eroded topsoil and depleted organic matter, depleted nutrients, and alternating drought stress and high rainfall (Eyasu, 2016). In high rainfall areas, excessive rainfall coupled with unfavorable temperature and precipitation is high enough to leach appreciable amounts of exchangeable basic cations (Mesfin, 2007). Its severity is extremely variable due to the effects of parent materials, land form, vegetation and climate pattern (Achalu et al., 2012). In moisture-stressed areas, acidification can also be caused by continuous application of acid-forming chemical fertilizers (Eyasu, 2002). Therefore the objective of this paper is to review the effects of soil acidity on soil productivity and its management options in western Ethiopia

\section{Soil Acidity in Western Ethiopia}

Soil acidity has become a serious threat to crop production in most highlands of Ethiopia in general and in the western part of the country in particular (Taye, 2007). An earlier study by Mesfin (2007) estimated that about $41 \%$ 
of arable lands of Ethiopia are affected by soil acidity/Al ${ }^{3+}$ toxicity. An inventory was made in 2006 to determine the status of soil acidity of Nitisols occurring in western and central Ethiopia and the results revealed that all samples were acidic though the degree varied from location to location (Abdenna et al., 2007). Soil acidity is expanding both in scope and magnitude in Ethiopia; severely limiting crop production (Wassie and Shiferaw, 2009; Wassie and Shiferaw, 2011; Tamene et al., 2017). Recently, Eyasu (2016) also reported that $80 \%$ of the Nitisols and Luvisol subgroup soils found in the north - central and south western high lands of Ethiopia are very strong to strongly acidic soils having $\mathrm{pH}$ of 4.5-5.5. As a result soil acidity and low soil fertility became one of the bottlenecks to sustain agricultural production and productivity in western Ethiopia.

Eyasu Elias (2016) suggested that the soils of north-central and south -western highlands of Ethiopia are now increasingly being depleted and turned into infertile ones as a result of mismanagement and unabated degradation processes that have taken their toll for centuries. He also summarized the major fertility challenges and constraints in this area as acidic soil reaction, low levels of organic matter and deficiencies of several essential plant nutrients.

Nitisols are the main soil classes dominated by acidity, and more than $80 \%$ of the landmasses originated from Nitisols could be acidic in nature, partly because of leaching of basic cations (IFPRI, 2010; Eyasu, 2016). The southwestern part of Ethiopia is the most productive and the most prone to acidity in the country. Areas known to be severely affected by soil acidity include Ghimbi, Nedjo, Hosanna, Sodo, Chencha, Hagere-Mariam, Endibir, and Awi Zone of the Amara regional state (Tamene et al., 2017). Despite these high-level statistics, the situation is not well understood in detail at the local level or with more up-to date estimates of severity. Although the extent and distribution as well as the causes and management of problematic soils of Ethiopia is not well documented, soil acidity in high rainfall areas, which comprises about $41 \%$ of the cultivated land (Mesfin, 2007), is becoming major production constraints (Getachew and Tilahun, 2017).

According to Abdenna (2013), soils from different districts of West Wollega, East Wollega and West Showa zones showed that the $\mathrm{pH}$ of these soils are out of normal $\mathrm{pH}$ range for crop production. Under such low $\mathrm{pH}$ the availability of essential nutrients are critically affected. Toxicity of aluminum to plants greatly affects root and shoot growth as well as nutrients and water absorption. Moreover, the activities of microorganisms which play pivotal roles in nutrient cycling in agro ecosystems are affected. Soils of West Wollega, East Wollega and West Showa zones of south western Ethiopia are acidic and the degree of acidity varies across districts. Most of the soils are very strongly to strongly acidic while a few soils are moderately to slightly acidic (Abdenna, 2013).

Anthropogenic factors such as inappropriate land use systems, monocropping, nutrient mining and inadequate supply of nutrients are aggravated the situation (Negassa et al., 2007; Wassie and Shiferaw, 2009; Tamene et al., 2017). According to Achalu et al. (2012), practices of exceptional deforestation, overgrazing and intensive cultivation of soils with low inputs over many years were the most causes of soil acidity, low soil quality and soil fertility in Western Oromia. The same authors opined that soil acidity problem that occurred particularly in eastern and western zones of Oromia was very critical and deserved immediate intervention to amend the soils for crop production. Also smallholder farmers in different districts in East and West Wollega zones have reported yield stagnation and even yield decline of crops and lack of response to application of urea and diammonium phosphate fertilizers because of soil acidity, which needs different amendments to improve soil fertility and acidity problems ( Abdenna, 2013). Thus, mitigation of soil acidity is a key for improving soil health and crop production in the country.

In order to achieve food security in the region through increased production and productivity of these acidic soils, fertilizing the soils with potassium and calcium is a necessity (Achalu et al., 2012). Moreover, ameliorating these acidic soils with lime to increase calcium contents and soil $\mathrm{pH}$, and organic amendments which complexes or arrest toxic aluminum are of greatest significance (Habtamu, 2015; Tamene et al., 2017). Thus, soil fertility research in western Ethiopia should gear towards site specific fertilizer recommendation such modeling lime, potassium and calcium fertilizer rates alone or in association with other primary essential nutrients (Wassie and Shiferaw, 2009; Abdenna et al., 2013).

\section{Soil Acidity and Its Effect on Crop Production}

There is a growing recognition, among specialists and policy makers that soil acidity is a major constraint to crop production in humid tropical environments. This is because of commonly associated effects of $\mathrm{Al}$ and Mn toxicity, nutrient deficiency and their adverse effects on crop growth (Fageria and Baligar, 2008).

Acidity produces complex interactions of plant growth-limiting factors involving physical, chemical, and biological properties of soil (Robarge, 2008). Soil erosion and low water-holding capacity are major physical constraints for growing crops on tropical soils. Calcium, magnesium, and phosphorous deficiencies or unavailabilities and aluminum toxicity are considered major chemical constraints that limit plant growth on acid soils (Menzies, 2003). Among biological properties, activities of beneficial microorganisms are adversely affected by soil acidity, which has profound effects on the decomposition of organic matter, nutrient mineralization, and immobilization, uptake, and utilization by plants, and consequently on crop yields (Fageria, 2009).

When soil $\mathrm{pH}$ is lower than optimal (5.5 and below) it reduces the solubility of nutrients needed for plant 
growth and usually lead to $\mathrm{Al}$ and $\mathrm{Mn}$ toxicity plus deficiency in $\mathrm{N}, \mathrm{P}, \mathrm{K}, \mathrm{Mg}, \mathrm{Ca}$, and various micronutrients (IFPRI, 2010; Marschner, 2012). Soil acidity has multiple implications for plant growth and other soil fertility issues; can lead to lack of or reduced response to ammonium phosphate and urea fertilizers, stunted root and plant growth due to nutrient deficiency (yields frequently reduced by 50 percent and can be reduced to 0 ), increased incidence of disease and toxicity (IFPRI, 2010; Fageria et al., 2011).

According to Merino et al. (2010), high aluminum (Al) concentrations as $\mathrm{Al}^{3+}$ represent an important growth and yield limiting factor for crops in acid soils $(\mathrm{pH} \leq 5.5)$. The most recognized effect of $\mathrm{Al}$ toxicity in plants is observed in roots. However, damages in the upper parts (including stem, leaves and fruits) may also be present. In addition, Al-toxicity triggers an increase in reactive oxygen species (ROS), causing oxidative stress that can damage the roots and chloroplasts, decreasing normal functioning of photosynthetic parameters.

The extent of damage posed by soil acidity varies from place to place depending on several factors. But there are also occasions where total loss of crops occurs due to soil acidity. Thus, mitigation of soil acidity for improving crop production and management of tropical soils is crucial to address the issues of food security, soil degradation and environmental quality including the global carbon cycle (Wassie and Shiferaw,2009; Achalu et al., 2012).

Therefore management of acidic soils should emphasize strategic research, integrating soil and water management with improved crop varieties and agronomic management. Such intervention may need to focus on organic matter enrichment in acidic soils, erosion control, and increased supply of cations. Moreover, acidic soil research is needed to provide complete information on the magnitude and extent of soil acidity (Getachew and Tilahun, 2017).

\subsection{Effect of soil acidity on coffee production}

Acidic conditions enhance the presence of trivalent cation $\left(\mathrm{Al}^{3+}\right)$ (Merino et al., 2010), which is the most toxic of all Al species available to plants (Kochian et al., 2004). This results in alterations of the physiological and biochemical processes of plants and consequently loss of productivity (Sumner and Noble, 2003). Under acidic conditions, some of the vital nutrients such as $\mathrm{P}, \mathrm{Ca}$ and $\mathrm{Mg}$ are made unavailable in the soil solution for plant uptake due to the abundance of elements such as $\mathrm{Al}$ and $\mathrm{Mn}$ (Mesfin, 2007). At low $\mathrm{pH}, \mathrm{Al}$ toxicity is reportedly the main stress factor for coffee plants (Cyamweshi et al., 2014). The high levels of Al in the soils results in the death of root cells, hindering root development. The damaged roots explore less soil volume, decreasing the amount of water and nutrients absorbed by the plants (Mendonca, 2007). Since exchangeable Al impairs the development of the root system, it interferes in $\mathrm{P}, \mathrm{Ca}$ and $\mathrm{Mg}$ absorption and movement by the plant (Kochian et al., 2004; Cyamweshi et al., 2014).

Also, the environmental conditions of the Ethiopian coffee growing tracts are part and parcel of tropical climate where by highly weathered tropical soils, such as Nitosols and Cambisols are dominant. They are acidic in nature, with $\mathrm{pH}$ values of 4.5 - 6.5 (Paulos, 1994). The clay minerals of these soils are dominated by oxides and hydroxides of $\mathrm{Al}$ and Fe, kaolinite and allophane and are prone to strong P fixation capacity (Mesfin, 2007).

In the major coffee growing areas of West Wollega, most soils are exposed to nutrient leaching over a long period resulting in low organic matter content and require careful management to support good crop yields (Likassa, 2014). He pointed out that soil acidity status and moisture content have significant influence on coffee production (to be higher or lower) than top soil macro nutrients. And Coffee production (yield) was increased with decreasing soil acidity and increasing soil moisture contents. Soil acidity limits or reduces crop production primarily by impairing root growth there by reducing nutrient and water uptake (Marschner, 2012). Moreover, low pH or soil acidity converts available soil nutrients in to unavailable form and also acidic soils are poor in their basic cations such as $\mathrm{Ca}, \mathrm{K}, \mathrm{Mg}$ and some micronutrients, which are as essential to coffee plant growth and development ( Cyamweshi et al., 2014).

Root length, root dry matter and number of lateral roots were the best plant traits for early Al tolerance screening (Kochian et al., 2015). The Al tolerance did not seem to be related to $\mathrm{pH}$ changes in the coffee rhizosphere (Mendonca, 2007). Coffee plants deficient in $\mathrm{Ca}$ and $\mathrm{Mg}$ might have their development reduced up to $50 \%$, in relation to plants cultivated in limed soils with low acidity and normal $\mathrm{Ca}$ and $\mathrm{Mg}$ levels (Andrade, 2001 as cited in Mendonca, 2007). The correction of soil acidity makes coffee plants more tolerant to drought and avoids the cation competition effect of $\mathrm{K}$, which is supplied in high doses due to its importance to grain fulfillment (Cyamweshi et al., 2014.)

Also repeatedly production of coffee without supplying the lost nutrient results in the total loss of minerals from the soil and subsequent decline in yield and vigor of the tree (Solomon et al., 2008a). The method of application, amount, frequency and time and type of fertilizers to be applied are dependent up on type of crop, inherent soil fertility status, the level of productivity, and cultural practices such as irrigation, spacing, mulching, e.t.c. and climatic condition (Melke and Ittana, 2015), though these aspects remain to be studied for coffee production in the country. 


\section{Management options}

Soil acidity is a combination of soil conditions that limit plant growth, and its management requires manipulation of various soil and plant factors in favor of better plant growth or crop production. These management practices may vary with severity of acidity, type of soil, type of farming practices, and socioeconomic conditions of the farmer (Fageria et al., 2011). Soil acidity can be minimized and monitored by using proper amendments (such as lime, gypsum and clean ash); balanced fertilizer and organic amendment applications; and appropriate use of acidifying fertilizer types (FAO, 2017) as elaborated below.

\subsection{Liming}

Lime application has been recognized and used as the main practice for ameliorating strong acidity which curtails the availability of nutrients required at high amounts in soils for maximum yields (Fageria and Baligar, 2008). Liming based on the quantity needed to neutralize exchangeable Al which is the principal factor responsible for poor crop growth in acid soils, and also supply $\mathrm{Ca}$ and Mg (Mesfin, 2007; Fageria et al., 2011) was beneficial to yield in soils with $\mathrm{pH}<5.5$ but not in moderately acid soils or when liming targeted $\mathrm{pH}=7.0$ or more (Fageria et al., 2011).

The most common and, in most cases, the most effective way to correct soil acidity is by applying lime. Liming is the practice of adding liming materials to acid soils for the purpose of increasing soil $\mathrm{pH}$ and maintaining a favorable soil environment for plant growth (Fageria, 2009). A more favorable root environment may be a consequence of the following effects: desirable soil $\mathrm{pH}$, decreasing the toxicity of $\mathrm{Al}$ and $\mathrm{Mn}$, increasing $\mathrm{Ca}$ and $\mathrm{Mg}$ supplies, enhancing the availability of $\mathrm{P}$ and Mo, improving mineralization of organic compounds, thereby improving N, S, and P uptake, improving soil biological activity, such as nitrogen fixation. The quantity of lime to be added depends on type of soil, liming material, crop species, cultivar, and economic considerations (Fageria et al., 2011).

Incorporation of lime or dolomite into the upper cultivable soil layer is an effective method for amelioration of acid soils (Mesfin, 2007). Lime can also be applied as a preventative treatment for soil infertility, and to supply calcium and magnesium to deficient soils (Fageria and Baligar, 2003). Liming raises the $\mathrm{pH}$ of acid soil, thus the action of nitrogen fixing bacteria becomes uninhibited and nitrogen fixation increases. Nitrogen mineralization from plant residues and organic matter has been reported to increases when lime is applied to acid soil. Although lime is primarily applied to raise soil $\mathrm{pH}$ and amend toxicities associated with acid soil, liming has also been used to improve soil structure. Application of liming agents is a prerequisite for optimal nutrient use efficiency in acid soils (FAO, 2017).

Toxicity of aluminum and manganese is the most important growth limiting factor in many acid soils. Besides this, the reduced uptake of calcium and magnesium in the soil solution can also be alleviated with the application of lime (Menzies, 2003). The application of liming materials to such soils can inactivate the iron and aluminum, thus increasing the level of plant available phosphorus and other macronutrient.

\subsection{Organic amendments}

An organic amendment is any material of plant or animal origin which is more or less decomposed and can be added to the soil to improve its physical, chemical and biological properties (CIAS, 2002; Wong and Swift, 2003; Samake, 2014). Typical examples include animal and plant manures, green manure, plant residues, vermicompost and compost, industrial and municipal wastes (Lekasi et al., 2001; Negassa et al., 2002; Gitari, 2013). These different forms of organic matter collectively represent a reservoir of nutrients that are critical to plant growth (Amini and Mohammad, 2015). Manure is the most common source that has been used as amendment in agriculture for improving soil fertility and crop yield (Ano and Ubochi, 2007). Therefore, the application of manure to reduce $\mathrm{Al}$ toxicity is a cheapest alternative approach to traditional liming for smallholder farmers (Habtamu, 2015). The release of cations and anions after the mineralization of manure affect nutrients balance of the soil solution and consequently its reaction. The cations can increase the potential cations and the base saturation of soil thus increasing soil pH and reducing Al toxicity (Wong and Swift, 2003; Ano and Ubochi, 2007; Zingore et al., 2008).

Additional benefits of organic matter addition to acid soils are improving nutrient cycling and availabilities to plants through direct additions as well as through modification in soils' physical and biological properties (Fageria and Baligar, 2003). A complementary use of organic manures and chemical fertilizers has proven to be the best soil fertility management strategy in the tropics (Ayodele and Shittu, 2014). Enhanced soil organic matter increases soil aggregation and water-holding capacity, provides source of nutrients, and reduces P fixation, toxicities of $\mathrm{Al}$ and $\mathrm{Mn}$, and leaching of nutrients (Fageria and Baligar, 2008).

Also application of compost to soil has received much attention as an environmentally favorable strategy to use the increasing amount of organic waste and to improve the soil organic matter (SOM) status of agricultural land ( $\mathrm{Lal}, 2002)$. Compost application to increase the quantity and improve the quality of SOM is particularly important in strongly weathered tropical soils to overcome the degradation of SOM and improve the soil carbon 
(C) sequestration (Lal, 2002; Fageria and Baligar, 2003).

\subsubsection{Farmyard manure}

Farmyard manure (FYM) supplies multiple nutrient elements to the crop and at the same time, maintains soil organic matter content (CIAS, 2002; Negassa et al., 2002). It has long been demonstrated that organic matter raises $\mathrm{pH}$ and thereby causes the precipitation of some aluminum ions as aluminum hydroxide. Manure amended soils correct acidity while at the same time provide mineralized ammonium-nitrogen and nitrate-nitrogen with increased availability of other nutrients at higher $\mathrm{pH}$ values (Gitari,2013). This can be attributed to buffering from organic acids and bicarbonates (Mesfin, 2007).

It has been perceived for a long time that animal manure lowers soil $\mathrm{pH}$ as some commercial nitrogen fertilizers do (Ayodele and Shittu, 2014). The main reason why manure raises soil pH is due to the presence of calcium and magnesium elements in it and its buffer capacity because of forming complexes with $\mathrm{Al}$ and $\mathrm{Fe}$ in acid soils (Wong and Swift, 2003; Gitari, 2013; Samake, 2014; Habtamu, 2015). Organic matter has been found to increase the soil's ability to hold and make available essential plant nutrients and to resist the natural tendency of soils to become acidic (Fageria and Baligar, 2003). As such, applying manure to acid soils not only supplies the much needed nutrients and organic colloids for plant growth but also reduces soil acidity, thus improving phosphorus availability and reduces aluminium toxicity (Ano and Ubochi, 2007; Mesfin, 2007).

Proton exchange between the soil and manure which contains some phenolic, humic-like material makes it capable of raising soil $\mathrm{pH}$ (Zingore et al., 2008). Another mechanism that has been proposed to explain the increase in soil $\mathrm{pH}$ by such materials as farmyard manure is the specific adsorption of humic material and/or organic acids (products of decomposition) onto hydrous surfaces of $\mathrm{Al}$ and Fe oxides by the exchange with corresponding release of $\mathrm{OH}^{-}$(Wong and Swift, 2003).

Returning organic amendments in form of livestock manures and crop residues to soil could be important in supplying crop nutrients as well as improving soil moisture conditions and increasing availability of $\mathrm{P}$ by stimulating microorganisms that solubilize soil P (Zingore et al., 2008). Cattle manure has potential to be used as an organic nutrient source in coffee production, while recycling coffee wastes such as pulp and pruning as direct inputs or in combination with green manures and live mulch in nutrient management were effective in promoting coffee growth and yield and also economically viable (Lekasi et al., 2001). The need for renewable, locally available and cheaper options for supplying nutrient to crops is increasingly becoming important because of the need for sustainable agriculture (Ahmad et al., 2006).

Also many researchers reported the combined application of the organic manures and ground lime ameliorated acidity problems greatly in tropical soils (Gitari, 2013; Ayodele and Shittu, 2014; Samake, 2014). It also increases the lime potential and the calcium ion concentration in the soil solution that ultimately results in the displacement of aluminum ions from the soil due to the presence of calcium and magnesium elements in it and its buffer capacity because of forming complexes with $\mathrm{Al}$ and $\mathrm{Fe}$ in acid soils (Gitari, 2013). Even then, the trend of organic matter addition as compost and farm yard manure should be encouraged to mitigate some of the problems associated with acid soils to promote productivity and production (Mesfin, 2007). Although cattle dung potentially constitutes a significant source of plant nutrients in tropical soils, this potential can only be realized in areas where farming systems and animal husbandry are organized to facilitate dung collection and storage (Ano and Ubochi, 2007).

\subsubsection{Coffee Husk and pulp Compost}

Composting of coffee by-products could be one mechanism of residue management by utilization. Currently, there is huge interest from regional and federal government to convert these resources into usable end products such as compost and minimize environmental pollution (Gezahegne et al., 2011).Coffee husk, a rich organic agricultural waste and potassium was good material for composting process ( Solomon, 2006; Dzung et al. 2013; Henok and Tenaw, 2014). As coffee husks have a high $\mathrm{C} / \mathrm{N}$ ratio, amendment with cow dung and fruit/vegetable wastes which are rich in easily biodegradable nitrogen compounds, was recommended in order to reduce the $\mathrm{C} / \mathrm{N}$ ratio and to increase the rate of degradation (Fikadu et al.,2014). Thus, co-composting of coffee husk with either cow dung or fruit/vegetable wastes can accelerate the composting process. The use of manure and fruit/vegetable wastes as cocomposting materials of coffee husks was shown to result in higher losses in carbon (Solomon et al., 2008). According to Solomon (2006), high quality compost can be prepared from a mixture of $70 \%$ coffee pulp/husk, $20 \%$ FYM and $10 \%$ top soil or 70\% coffee pulp, 10\%FYM,10\% leguminous plant materials and 10\% top soil.

Some literatures (Taye et al., 2003; Solomon et al., 2008; Kasongo et al., 2011; Dzung et al., 2013; Kasongo et al., 2013; Nduka et al., 2015) have indicated that coffee waste is a valuable organic amendment, particularly for highly weathered soils of the humid tropics. Kasongo et al. (2011) demonstrated the efficiency of coffee waste in improving the physico-chemical quality of Arenosols under humid tropical conditions. Coffee waste application significantly raised the $\mathrm{pH}$ above 5.5 within 3 months and throughout the entire incubation period. It also significantly improved the supply of total $\mathrm{N}$, availability of $\mathrm{P}, \mathrm{Ca}, \mathrm{Mg}$ and $\mathrm{K}$, whereas it immobilized the phytotoxic micronutrient $\mathrm{Mn}$ and mobilized $\mathrm{Fe}$. The $\mathrm{C} / \mathrm{N}$ ratio of the coffee waste amended soils was found within the optimal range (10-14). Soil structural improvement caused by increased organic matter promoted water 
retention. The relatively high alkalinity and probably the proton consuming ability of humic materials, as well as the high nutrient contents in coffee waste, are considered the main factors responsible for the reduced soil acidity and improved nutrient supply and nutrient retention of the amended soils. This is of particular importance as it indicates the value of coffee waste as an alternative for small-scale farmers who cannot afford to regularly purchase and apply mineral fertilizers (Kasongo et al., 2011).

Also the application of coffee waste greatly stimulated uptake of $\mathrm{Ca}, \mathrm{Mg}, \mathrm{K}, \mathrm{N}$ and $\mathrm{P}$, resulting in a significantly increased dry matter $(\mathrm{DM})$ production over three consecutive cropping cycles of rye grass. Dry matter increased with increasing the coffee waste application rate $(0,5,1020 \mathrm{t} / \mathrm{ha})$ of at least 52,87 and $81 \%$ compared with the unamended controls was obtained for the first, second and third cuts, respectively. Soil analysis after cultivation found that all coffee waste amended soils still contained available macronutrients $(\mathrm{Ca}, \mathrm{Mg}, \mathrm{K}, \mathrm{N})$, which could produce residual effects in subsequent crops. Furthermore, coffee waste application increased soil $\mathrm{pH}$ owing to its liming effect. This brought about an increase in cation exchange capacity with substantial reduction in phytotoxic $\mathrm{Al}$ and a decrease in availability of a number of metals $(\mathrm{Cu}, \mathrm{Zn}, \mathrm{Mn}$ and $\mathrm{Fe}$ ) and significantly reduced their uptake by ryegrass (Kasongo et al., 2013).

Kasongo et al. (2011), indicated that the marginal and unproductive tropical sandy soils can be improved by the application of coffee waste for the optimization of crop production. The study also suggests that the increased yield (DM) of Italian ryegrass on coffee waste amended soils was the result of improved chemical and physical soil properties by coffee waste application. These benefits of coffee waste application include its capacity to: (i) increase the soil $\mathrm{pH}$, (ii) supply soil nutrients $(\mathrm{N}, \mathrm{K}, \mathrm{P}, \mathrm{Ca}, \mathrm{Mg}$, etc.) and (iii) increase water and nutrient retention (Nduka et al., 2015).

Taye et al. (2003) and Taye (1998) reported that the incorporation of different ratios of organic mixes which contained decomposed coffee husk and farmyard manure significantly affected the status of the soil physicochemical properties with increasing proportion of organic amendments on nursery media at south western Ethiopia.

The organic matter in coffee waste contains more $\mathrm{N}$ and $\mathrm{K}$ than common fertilizers (cow manure, compost, farm residue, chicken manure) ( Solomon, 2006; Kasongo et al., 2011; Henok and Tenaw, 2014). Magnesium and Calcium are additional nutrient to N, P and $\mathrm{K}$ in coffee husk. However, the better performance of treatments with coffee husk over NPK could be due to the additional presence of $\mathrm{Mg}$ and $\mathrm{Ca}$ in coffee husk. The major mineral elements present in the coffee husk were $\mathrm{N}, \mathrm{P}, \mathrm{K}, \mathrm{Mg}, \mathrm{Ca}$ and $\mathrm{Na}$ (Solomon et al., 2008). Therefore agricultural wastes such as coffee husk are of great efficient importance as degradable organic matter for composting ( Solomon,2006; Nduka et al., 2015). As a result, application of coffee husk compost to tropical sandy soils has shown that it has the potential to be used as a liming material and as 'NPK fertilizer' because of its mineral content compositions such as $\mathrm{N}, \mathrm{P}, \mathrm{K}, \mathrm{Mg}, \mathrm{Ca}$ and $\mathrm{Na}$. In addition, it can increase water and nutrient retention ( Kasongo et al., 2011; Nduka et al.,2015).

According to Nduka et al. (2015), coffee husk improved physico-chemical properties of soil, the nutrient in the nursery soil medium and actively supported the morphological development of the cashew seedling. Since good morphological development of seedling enhances their better field establishment, the use of coffee husk to amend nursery soil is recommended. The appropriation of this organic material in agricultural system of nursery seedling production will profitably claim the waste (i.e. coffee husk) and ultimately supply nutrient to growing seedlings without adverse impact on soil biomes.

Dzung et al. (2013) indicated that cultivation of coffee by using only chemical fertilizers leaded to degradation of the soil and coffee production became unsustainable. Application of compost prepared from coffee husk improved the fertility of the soil and $\mathrm{pH}$ of the soil. Particularly, OC\% and $\mathrm{N} \%$ and total phosphorus enhanced significantly in comparison with the control. Available nutrients and cationic exchange also improved clearly compared with the control. In addition, application of coffee husk compost (CHC) improved physical structure of the soil such as bulk density, particle density and pore space of the soil. Improvement of pore space makes plants adsorption of the nutrients better and effective microorganisms' growth stronger. It is lead to reduce using chemical fertilizer and maintain the fertility of the soil. After three years of the compost application on the coffee field, the study concluded that applying only chemical fertilizers in cultivation of coffee leaded to reducing in $\mathrm{pH}, \mathrm{OC} \%$, total $\mathrm{N} \%, \mathrm{P} \%, \mathrm{~K} \%$ and available nutrients and increasing in degradation of the soil (Dzung et al., 2013).

According to Solomon et al. (2008b), compost prepared from coffee processing by-products provided much of the mineral nutrients required by the coffee tree for normal growth and sustained yield. The previous work mentioned above therefore seems to confirm that organic materials such as coffee husk do release N, P, K, Ca and $\mathrm{Mg}$ into soil when used alone or in combination with NPK. Application of fertilizers as amendments improved the chemical characteristics of the soil. This was in reference to the Integrated Soil Fertility Management (ISFM) principle. The reduction in mineral fertilizer application through their supplementation with organic sources, such as coffee husk makes the use of soil nutrient amendments affordable to small holder farmers, guarantees and improves soil health (Nduka et al., 2015). 


\section{Conclusion}

The original ecology of the major crop producing growing areas in western Ethiopia is being disturbed with the high intensity of deforestation and land degradation. This and the prevailing high rain fall have resulted in severe erosion, organic matter depletion, exposure of the less fertile sub-soils and increased soil acidity in major crop producing areas. As low $\mathrm{pH}$ affects the availability of nutrients particularly that of phosphorus and other macronutrients, correction of the low $\mathrm{pH}$ through liming, and/or application of organic materials is critical for sustainable management of these soils. Agricultural liming is proved a good way of correcting soil $\mathrm{pH}$ along with supplying calcium to the soil. Another potential organic amendment sources in coffee producing areas of western Ethiopia were coffee pulp and husk, by products from wet and dry coffee processing respectively. These coffee by-products are utilized in other coffee producing countries as soil amendments especially in highly weathered soils. While in Western Ethiopia enormous quantities are either dumped into streams or burnt in big piles, with contributions to environmental hazards. Therefore, farmers should be encouraged to increase productivity of the acidic soils by using lime and organic amendments which is easily available such as composted coffee wastes (coffee husk and pulp).

\section{References}

Abdenna Deressa, Bikila Bote, and Hirpa Legesse. 2013. Evaluation of Soil Cations in Agricultural Soils of East Wollega Zone in South Western Ethiopia. Sciences, Technology and Arts Research Journal, 2(1): 10-17

Abdenna Deressa, Negassa Chewaka and Tilahun Geleto .2007. Inventory of Soil Acidity Status in Crop Lands of Central and Western Ethiopia. In: Utilization of diversity in land use systems: Sustainable and organic approaches to meet human needs. A paper presented on Tropentag, October 9-11, 2007 Witzenhausen, Germany.

Abdenna Deressa. 2013. Evaluation of Soil Acidity in Agricultural Soils of Smallholder Farmers in South Western Ethiopia. Sciences, Technology and Arts Research Journal, 2(2): 01-06

Achalu Chimdi, Heluf Gebrekidan, Kibebew Kibret, and Abi Tadesse. 2012. Effects of Liming on Acidity-Related Chemical Properties of Soils of Different Land Use Systems in Western Oromia, Ethiopia. World Journal of Agricultural Sciences, 8 (6): 560-567.

Ahmad R., A. Naseer, Z.A. Zahir, M. Arshad, T. Sultan, M.A. Ullah, 2006. Integrated use of recycled organic waste and chemical fertilizers for improving maize yield. Int J Agric Biol, 8(6):840-843

Alhassane Samake.2014. Use of Locally Available Amendments to Improve Acid Soil Properties and Maize Yield in the Savanna Zone of Mali. A Thesis submitted to the Department of Crop and Soil Sciences, Faculty of Agriculture, College of Agriculture and Natural Resources, Kwame Nkrumah University of Science and Technology, Kumasi, in partial fulfilment of the requirements of the degree of doctor of philosophy in soil science. 210pp

Amini, Sh. and A.Mohammad. 2015. Investigation the Effect of Conservation Tillage on Soil Organic Matter (SOM) and Soil Organic Carbon (SOC) (The Review), 8(3): 16-24.

Ano, A. O., and C. I. Ubochi, 2007. Neutralization of Soil Acidity by Animal Manures : Mechanism of Reaction. African Journal of Biotechnology, 6 (4):364-368.

Ayodele O. J and O. S. Shittu, 2014. Fertilizer, Lime and Manure Amendments for Ultisols Formed on Coastal Plain Sands of Southern Nigeria. Journal of Agriculture, Forestry and Fisheries. 3(6): 481-488.

Center for Integrated Agricultural Systems (CIAS).2002.Building Soil Organic Matter with Organic Amendments. A resource for urban and rural gardeners, small farmers, turf grass managers and large-scale producers. College of Agricultural and Life Sciences, University of Wisconsin-Madison.

Cyamweshi R. A., N.L. Nabahungu, A. Mukashema, V. Ruganzu, M.C. Gatarayiha, A. Nduwumuremyi and J.J. Mbonigaba, 2014. Enhancing nutrient availability and coffee yield on acid soils of the central plateau of southern Rwanda. Global Journal of Agricultural Research, 2(2): 44-55.

Dzung, N. A., T. T. Dzung and V.T.P. Khanh, 2013. Evaluation of Compost for Improving Soil Fertility and Sustainable Coffee Production in Rural Central Highland of Vietnam. Resources and Environment, 3(4): 77 82

Eyasu Elias, 2002. Farmers Perceptions of change and management of soil fertility. SOS Sahel-Sahel and Institute of development studies. Addis Ababa Ethiopia. 252pp.

Eyasu Elias, 2016.Soil of Ethiopian Highlands: Geomorphology and properties.CASCAPE Project, ALTERA, Wageningen University and Research Centre (Wageningen UR). The Netherlands.385pp

Fageria, N. K, 2009. The Use of Nutrients in Crop Plants. CRC Press, New York. 430pp

Fageria, N. K., V.C. Baligar, and C.A. Jones, 2011. Growth and Mineral Nutrition of Field Crops ( $3^{\text {rd }}$ ed). CRC Press, New York. 550pp

Fageria, N.K. and V.C. Baligar, 2003. Fertility management of tropical acid soils for sustainable crop production, 359 - 385. In: Z. Rengel, Editor, Hand book of soil acidity. University of Western Australia, Perth, Western Australia, Australia. 
Fageria, N.K. and V.C. Baligar, 2008. Ameliorating soil acidity of tropical oxisols by liming for sustainable crop production. Advance in Agronomy, 99: 345 - 400.

FAO, 2017. Voluntary Guidelines for Sustainable Soil Management: Food and Agriculture Organization of the United Nations Rome, Italy.16 pp.

Fekadu Shemekite, M.G. Brandon, I. H. Franke, B. Praehauser, H.Insam and Fassil Assefa, 2014. Coffee husk composting: An Investigation of the Process Using Molecular and Non-Molecular Tools. Waste Management, 34(3): 642-652.

Getachew Agegnehu and Tilahun Amede. 2017. Integrated soil fertility and plant nutrient management in tropical agro-ecosystems: A review. Pedosphere, 27(4): 662-680

Gezahegne Barecha, Fikre Lamessa and Mulatu Wakjira.2011. Exploring the suitability of coffee pulp compost as growth media substitute in greenhouse production. Int J Ag-ric Res., 6(3):255-267

Gitari, H.I., 2013. Lime and Manure Application to Acid Soils and their Effects on Bio-Chemical Soil Properties and Maize Performance at Kavutiri-Embu County (Doctoral dissertation, Kenyatta University).75pp.

Habtamu Admas Desta. 2015. Reclamation of phosphorus fixation by organic matter in acidic soils (Review): Global Journal of Agriculture and Agricultural Sciences, 3 (6); 271 -278

Hede, A.R., B. Skovmand and J. Lopez-Cesati, 2001. Acid Soils and Aluminum Toxicity. In: Reynolds, M.P., Ortiz-Monasterio, J.I and McNab, A (eds.). Application of Physiology in Wheat Breeding, Mexico, D.F.: CIMMYT.

Henok Kassa and Tenaw Workayehu.2014.Evaluation of some additives on coffee residue (coffee husk and pulp) quality as compost, southern Ethiopia. International Invention Journal of Agricultural and Soil Science, 2(2):14-21

International Food and Policy Research Institute (IRPRI). 2010. Fertilizer and Soil Fertility Potential in Ethiopia. Constraints and opportunities for enhancing the system. Working Paper.42pp

Kasongo R. K., A. Verdoodt, P. Kanyankagote, G. Baert, and E. Van Ranst. 2011. Coffee Waste as an Alternative Fertilizer with Soil Improving Properties for Sandy Soils in Humid Tropical Environments. Soil Use and Management, 27: 94-102

Kasongo, R. K., A. Verdoodt, P. Kanyankogote, G. Baert, \&E.Van Ranst. 2013. Response of Italian Ryegrass (Lolium Multiflorum Lam.) to Coffee Waste Application on a Humid Tropical Sandy Soil. Soil Use and Management, 29: 22-29

Kilian B., J. Connie, L. Pratt and A. Villalobos, 2006. Is sustainable agriculture a viable strategy to improve farm income in Central America? A case study on coffee. J Bus Res, 59(3):322-330

Kochian L.V., M. A. Pineros, J. Liu and J.V. Magalhae, 2015. Plant Adaptation to Acid Soils: The Molecular Basis for Crop Aluminum Resistance. Annual Review of Plant Biology, 66:571-598

Kochian L.V., O.A. Hoekenga and M.A. Pineros, 2004. How do crop plants tolerate acid soils mechanisms of aluminum tolerance and phosphorous efficiency? Annual Review of Plant Biology, 55: 459 - 493.

Lal R., 2002. The potential of soils of the tropics to sequester carbon and mitigate the greenhouse effect. $A d v$. Agron. 74:155-192

Lekasi J., J. Tanner, S. Kimani and P. Harris, 2001. Managing manure to sustain smallholder livelihoods in East African highlands: DFID/NRSP/HYDRA

Likassa Ebisa.2014. Effect of Dominant Shade Trees on Coffee Production in Menesibu District, West Oromia, Ethiopia. Science, Technology and Arts Research Journal, 3(3):18-22

Marschner, P., 2012. Mineral Nutrition of Higher Plants ( $3^{\text {rd }}$ eds.) Acadamic Press Elsevier Ltd., United States of America. 668p.

Melke Abayneh and Fisseha Ittana. 2015. Nutritional Requirement and Management of Arabica Coffee (Coffea arabica L.) in Ethiopia : National and Global Perspectives. American Journal of Experimental Agriculture, 5 (5): $400-418$

Menzies N. W., 2003. Toxic Elements in Acid Soils: Chemistry and Measurement. 267-296. In: Zdenko Rengel (ed.) Handbook of Soil Acidity. University of Western Australia, Perth, Western Australia, Australia.

Merino G.C., M. Alberdi, A.G. Ivanov and M. Reyes-Diaz, 2010. $\mathrm{Al}^{3+}-\mathrm{Ca}^{2+}$ interaction in plants growing in acid soils: Al-phyto toxicity response to calcareous amendments. J. soil. Sci. plant nutr. 10 (3): 217 -243.

Mesfin Abebe. 2007. Nature and Management of Acid Soil in Ethiopia. Haramaya University. Haramaya, Ethiopia.99pp

Nduka, B.A., D. B. Adewale, O.S.O. Akanbi, and K. B. Adejobi. 2015. Nursery Soil Amendments for Cashew Seedling Production: A Comparative Analysis of Coffee Husk and NPK. Journal of Agricultural Science, 7(3):111-122

Negassa Waktole, Fite Getaneh, Abdena Deressa, and Berhanu Dinsa. 2007. Integrated use of organic and inorganic fertilizers for maize production. In Utilization of diversity in land use systems: Sustainable and organic approaches to meet human needs. Conference Tropentag 2007, October 9-12, 2007, Witzenhousen, Kassel, Germany. 
Negassa Waktole, K. Negisho, D. K. Friesen, J. Ransom, and A. Yadessa. 2002. Determination of Optimum Farmyard Manure and NP Fertilizer for Maize under the Farmers' Conditions. pp 387-393. In: proceeding of 7th East and South African Regional Maize conference, 11-15th February 2002, Nairobi, Kenya.

Pandey, A., C. R. Soccol, P. Nigam and D. Brand. 2000. Biotechnological Potential of Coffee Pulp and Coffee Husk for Bioprocesses. Biochemical Engineering Journal, 6:153-162

Paulos Dubale. 1994. Ecology and soils of major coffee growing regions of Ethiopia. In Mineral Fertilization of Coffee in Ethiopia (Paulos Dubale, ed.). Institute of Agricultural Research (IAR), Addis Ababa, Ethiopia.

Ritchie, G.S.P., 1989. The chemical behavior of aluminum, hydrogen and manganese in acid soils. 1-60. In Robson, A.D., ed., Soil Acidity and Plant Growth. Sydney: Academic Press.

Robarge W.P., 2008. Acidity. In: Encyclopedia of Soil Science, Encyclopedia of Earth Sciences Series (Ed.: Ward Chesworth). 860pp.

Solomon Endris, Tesfu Kebede, Tesfaye Yaekob, Yared Kassahun and Jafar Dawid.2008. The Challenges and Opportunities of Organic Fertilizers in Coffee.226-233. In: Coffee Diversity and Knowledge (Girma Adugna; Bayetta Belachew; Tesfaye Shimber; Endale Taye. and Taye Kufa. ed.).Proceedings of National Workshop Four Decades of Coffee Research and Development in Ethiopia, 14-17 August 2007, Addis Ababa (Ghion hotel), Ethiopia.

Solomon Endris.2006.Accelerated composting of coffee processing by products: an organic option for soil fertility management in the coffee based cropping system of south western Ethiopia. Proceeding of $21^{\text {st }}$ International scientific conference on coffee science (ASIC), Montpelier, France, pp 1084-1089.

Sumner, M.E. and A.D. Noble, 2003. Soil acidification: the world story. 1 - 28. In: Rengel, Z. (eds.), Hand book of soil acidity. University of Western Australia, Perth, Western Australia, Australia.

Tamene Lulseged; Amede Tilahun; Kihara J; Tibebe Degefi; Schulz S. (eds.). 2017. A review of soil fertility management and crop response to fertilizer application in Ethiopia: towards development of site- and contextspecific fertilizer recommendation. CIAT Publication No. 443. International Center for Tropical Agriculture (CIAT), Addis Ababa, Ethiopia.86p

Taye Bekele.2007. An overview of acid soils their management in Ethiopia paper presented in the third International Workshop on water management (Wterman) project, September, 19-21, 2007, Haromaya, Ethiopia.

Taye Kufa, Mesfin Abebe, Paulos Dubale, 2003. Contribution of organic amendment to physico-chemical conditions of coffee nursery media, 25-40. In: Tilahun A, Eylachew Z (eds). Proceedings of the Sixth Conference of the Ethiopian Society of Soil Science (ESSS) on Challenges of Land Degradation to Agriculture in Ethiopia, Feb 28-March 1, 2002, Addis Ababa, Ethiopia.

Taye Kufa.1998. Response of Arabica coffee (Coffea arabica L.) to various soil fertility management. Thesis presented to the school of graduate studies Haramaya University of Agriculture. In partial fulfillment of the requirement for the degree master of science in agriculture (agronomy), Haramaya, Ethiopia.137pp

Wassie Haile and Shiferaw Boke. 2009. Mitigation of soil acidity and fertility decline challenges for sustainable livelihood improvement: research findings from southern region of Ethiopia and its policy implications.

Wassie Haile and Shiferaw Boke. 2011. On-Farm Verification of Lime and NPK Fertilizers Effects on the Tuber Yield of Irish Potato (Solanum Tuberosum) on Some Acidic Soils of Southern Ethiopia. Journal of the Dry lands, 4(1): 283-288.

Wong, M. T. F., and Swift, R. S. 2003. Role of organic matter in alleviating soil acidity. 337-358. In "Handbook of Soil Acidity', (Z. Rengel, ed.), University of Western Australia, Perth, Western Australia, Australia.

Zingore, S., R.J. Delve, J. Nyamangara and K.E. Giller, 2008. Multiple benefits of manure: The key to maintenance of soil fertility and restoration of depleted sandy soils on African smallholder farms. Nutrient Cycling in Agro ecosystems, 80: 267 - 282. 